Cita bibliográfica: Almeida García, F. y Jiménez Serrano, S. (2018). Turismo y terrorismo. Crisis y medios de comunicación. Investigaciones Turisticas (16), pp. 23-45. http://dx.doi.org/10.14198/INTURI2018.16.02

\title{
Turismo y terrorismo. Crisis y medios de comunicación
}

\author{
Tourism and terrorism. Crisis and media
}

Fernando Almeida García, Universidad de Málaga. falmeida@uma.es

Sandra Jiménez Serrano, Universidad de Málaga. jimenezserrano.sandra@gmail.com

\section{RESUMEN}

La actividad turística es muy sensible a cualquier situación que afecte a la seguridad del turista. El terrorismo ha encontrado a través de los atentados en los espacios turísticos un gran eco en los medios de comunicación y una herramienta de presión hacia los gobiernos de los países afectados. Los medios de comunicación juegan un papel fundamental en la trasmisión de los sucesos relacionados con el terrorismo. Esta investigación estudia la afección del terrorismo en el panorama turístico de diversos países y destinos. Se realiza un análisis de la influencia que ejercen los medios de comunicación en la sociedad y los intereses relacionados con la difusión de estas noticias. Esta investigación se realiza mediante un análisis documental de noticias y fuentes estadísticas. Este estudio muestra que los medios de comunicación seleccionan las noticias relacionadas con el terrorismo por afinidad geográfica, cultural y económica, las noticias de los atentados europeos tienden a mostrar el hecho como asunto puntual y bajo control y que la mayor parte de los atentados terroristas se producen fuera del ámbito occidental.

Palabras clave: terrorismo, turismo, seguridad, yihadismo, medios comunicación

\section{ABSTRACT}

Tourism activity is highly sensitive to any situation that affects the safety of tourists. Through the attacks perpetrated in tourist destinations, terrorism has been given wide coverage in the media and has found a tool to pressure the governments of the affected countries. The media play a key role in transmitting events related to terrorism. This research studies the blight of terrorism in the tourist panorama of several countries and destinations. An analysis of the influence of the media on society and the interests related to the diffusion of this news is carried out. The research is conducted through a documentary analysis of news and statistical sources. This study shows that the media selects the news related to terrorism based on geographic, cultural and economic affinity; reports of European attacks tend to portray them as one-off occurrences that are under control and that most of the terrorist attacks occur outside the western area.

Keywords: terrorism, tourism, security, jihadism, communication media 


\section{INTRODUCCIÓN}

La naturaleza de la actividad turística lleva intrínseco el factor inseguridad al alejar de la zona de confort a la persona que desee realizarla. Por esta razón, la seguridad que proporcione un territorio es un factor decisivo para elegir un destino u otro. Proclamarse como "destino seguro" es un gran reclamo, aunque puede alterarse a causa de diferentes agentes externos, como el terrorismo.

El terrorismo es un método radical para extender o imponer una ideología y ejercer el control político sobre una sociedad mediante la violencia, en entornos diversos, ya sea en países en desarrollo o desarrollados (Zuinaga, 2011). Este no es un fenómeno reciente, quedando acuñado este término a partir del reinado del terror durante la Revolución Francesa. A lo largo de la historia se han formado muchos grupos que han intentado imponer sus ideales mediante la violencia, lo que lo diferencia de fenómenos anteriores es la estrecha relación con la propaganda y los medios de comunicación. Aunque el terrorismo es un fenómeno complejo y multicausal, a decir de algunos autores (Rodrigo, 1991:27) "es por antonomasia un acto comunicativo". La estrecha relación que tiene el terrorismo con los medios de comunicación, una necesidad teatral, es lo que lo diferencia de otras actividades delictivas (Veres, 2004).

Durante buena parte del siglo XIX y XX, ha predominado un terrorismo de carácter más político, apoyado en diversas ideologías y objetivos (Laqueur, 2003). La relación de estos grupos con los medios de comunicación ha ido aumentado, conforme aquellos han ido incrementando su papel en la sociedad. Esta situación ha sido especialmente importante en los países occidentales en los que los grupos mediáticos tienen un papel fundamental en las sociedades democráticas (Veres, 2004). En estos países, el terrorismo de corte ideológico-político decayó de forma clara a partir de la caída del Muro de Berlín, viniendo a ser sustituido por el terrorismo de base religiosa, al menos desde el punto de vista de los medios. A esta situación contribuyó especialmente los atentados del 11 de septiembre de 2001 en Estados Unidos, el gran centro de los medios de comunicación a escala global (Calduch, 2001; Bossong, 2012).

Las corrientes religiosas más conservadoras del islam entienden que la solución a los problemas que padecen diversos países musulmanes es una interpretación más rigurosa de la religión. Además, estas corrientes identifican a los países occidentales como una de las causas de los males que aquejan a los países musulmanes. Los grupos terroristas islámicos tienen como objetivo combatir a los enemigos del islam, y con ello a los países occidentales. Los grupos religiosos integristas pretenden derrocar a todo gobierno que no sea afín a sus creencias, y esto incluye a los propios gobiernos locales que no tengan como objetivo declarar un estado islámico.

Desde el 2000 al 2014, el 87\% de los atentados perpetrados por organizaciones terroristas islamistas tuvieron lugar en países con una población mayoritariamente musulmana. Y entre 2013 y 2017, sólo el 5\% de todos los incidentes relacionados con el terrorismo se localizaron en Europa (Global Terrorism Database, 2018). Sin embargo, en los últimos siete años, se está produciendo en Occidente un incremento del terrorismo llevado a cabo por células extremistas (Gráfico 1). Por otro lado, hay que señalar que, de los 1600 millones de musulmanes existentes en el mundo, se estima que únicamente una muy pequeña porción, entre 85.000 y 106.000 personas, pertenecerían a grupos terroristas (Pew Research Center, 2015). 
Gráfico 1. Incidentes relacionados con el terrorismo en Europa Occidental

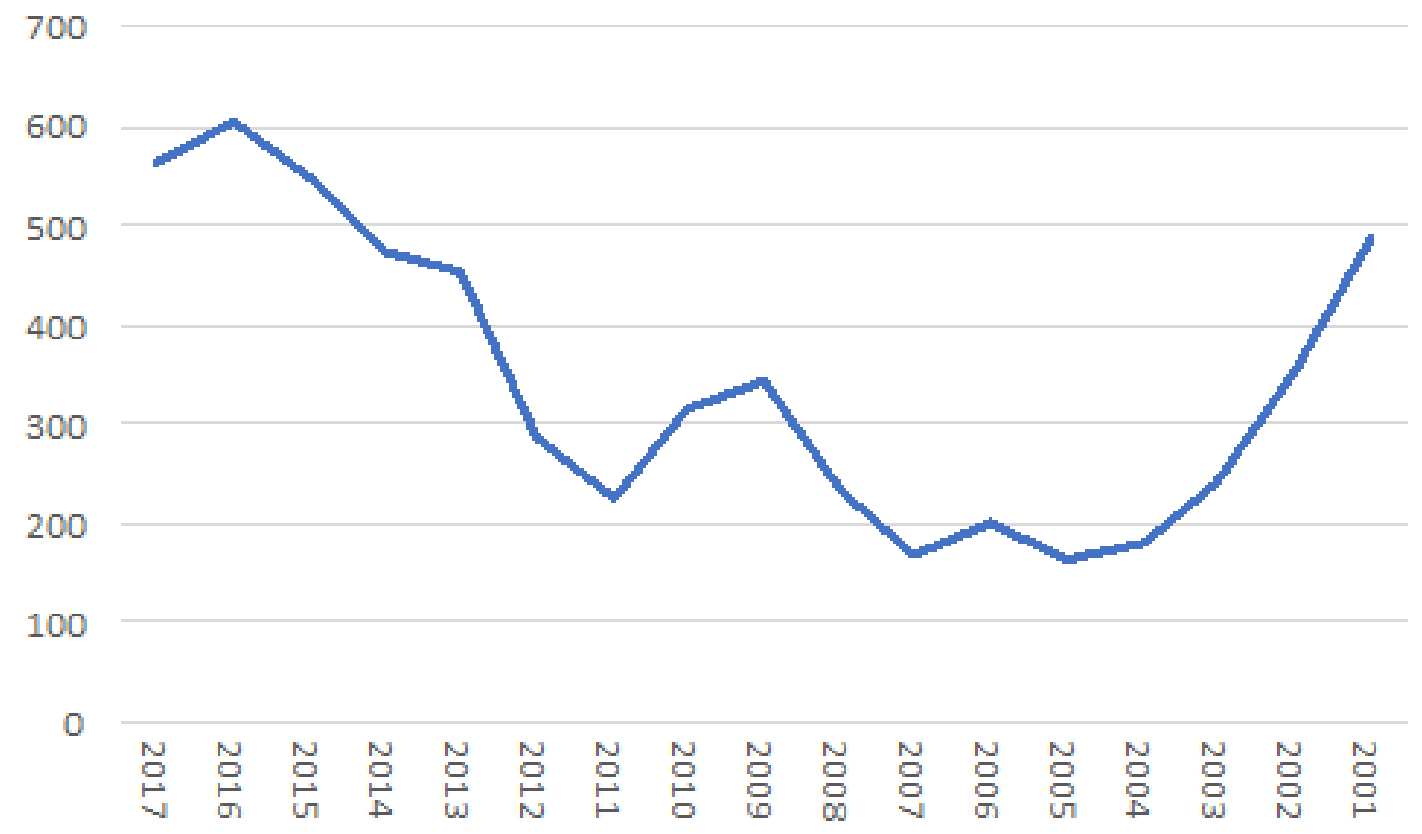

Fuente: Global Terrorism Database, 2018.

En la actualidad, la población occidental es bastante consciente del peligro que supone el terrorismo, recibiendo la información de que no hay casi ningún espacio seguro. Cualquier lugar emblemático, turístico o cultural, donde se concentren personas pueden ser blanco de un ataque terrorista, de modo que hay que aumentar las medidas de seguridad para prevenirlos. Se presupone que los países occidentales tienen elevados índices de seguridad, considerándose a priori como destinos seguros. No obstante, los grupos terroristas sortean los sistemas de seguridad para sembrar el pánico, y demostrar que ningún lugar está a salvo de ser objetivo del terrorismo (Berenguer, 2016).

A partir del 2010, a causa de la oleada de incidentes terroristas en Europa y en otros países mediterráneos de gran reclamo turístico, como Turquía, Túnez o Egipto, la población occidental comenzó a contemplar como inseguro los tradicionales espacios turísticos del sur y este del Mediterráneo. Esta sensación de inseguridad transmitida por los medios de comunicación se ha mantenido en el tiempo. Los atentados que se han producido desde ese periodo, unido a la inestabilidad generada por la Primavera Árabe, se han aliado para afectar de forma grave al sector turístico de esta zona (Bossong, 2012).

El terrorismo genera tanto perjuicios morales y personales como también graves impactos negativos en la economía del país. El terrorismo afecta a intangibles de gran valor en el campo turístico como es la imagen del destino y en especial, la percepción de seguridad. La transmisión de inseguridad debido a la actividad terrorista puede beneficiar a algunos países en detrimento otros.

Este estudio analiza el impacto del terrorismo en la actividad del turismo, utilizando principalmente los medios de comunicación como fuente de información. Se analiza 
la repercusión del terrorismo en la actividad turística de algunos países, se analizan casos concretos de ciudades turísticas que han sufrido atentados terroristas y se hace un análisis comparativo de noticias a través de medios de comunicación. Por último, se estudia la objetividad de los medios de comunicación en relación a la transmisión de noticias relacionadas con la actividad terrorista.

\section{MARCO CONCEPTUAL}

\subsection{La gestión de la información por parte de los medios de comunicación}

Los medios de comunicación tienen un papel transcendental en la creación de opinión pública y en la generación de crítica social (Rubio, 2009). Aunque dicha capacidad crítica y la objetividad en la selección de la información puede estar mermada por la continua interferencia de factores externos a los medios de comunicación (Díaz, 2008; Chomsky, 2010). Chomsky (2010) destaca diversas estrategias que desarrollan los medios para dirigir la atención del espectador hacia determinadas noticias. Entre estas estrategias se encuentran la dilación o la celeridad en el tratamiento de las noticias, entre las que se incluyen las relacionadas con el terrorismo.

Los medios de comunicación difunden y seleccionan las noticias en base a una serie de criterios y objetivos, que posteriormente se comentan, y que deben estar acordes a la línea editorial del medio y los valores de la persona receptora de la información. En esta selección de la información es determinante el tiempo de publicación o difusión de una noticia. De un momento a otro, se deja de transmitir una noticia, lo que no quiere decir que ésta haya desaparecido o tenga una menor relevancia (Gans, 1979; Rodrigo, 1989). La importancia de la información se diluye con facilidad en un corto lapso.

A pesar de que los medios tienen una evidente función social, estos transmiten la información atendiendo a su línea editorial, que no tiene por qué estar en línea con los intereses de la mayoría de la sociedad (Ribas, 2002). Este autor resalta que la valoración de las noticias se realiza en función de tres criterios determinantes:

a) El interés. La capacidad de entretener influye en la selección de las noticias o del orden en que serán transmitidas. Los medios de comunicación conocen los intereses del público al que se dirigen y, para ganar audiencia, eligen una información atractiva (Heath y Palenchar, 2008).

b) La importancia. Este factor depende del grado y el nivel jerárquico de los sujetos implicados en el asunto. Por ejemplo, si la persona implicada en una acción tiene un grado de poder social legitimado institucionalmente, es más fácil que se convierta en noticia. También es determinante la importancia o el impacto sobre el propio país o el ámbito cultural de la audiencia. En este sentido, Ribas (2002) señala lo siguiente:

“En España, parece ser que solo existen países europeos (y no todos), los de Oriente Medio y Estados Unidos. El resto del mundo sólo será noticia en caso de que se den grandes catástrofes o se combinen otros valores-noticia" (2002:504). 
c) Por último, la cantidad de personas implicadas en el asunto también es determinante para la evaluar importancia de una noticia. Siguiendo la Ley de McLurg (periodista que creó la sistematización práctica de los valores-noticias), un europeo equivale en importancia a 28 chinos (Ribas, 2002).

El grado de objetividad al transmitir una noticia en los medios de comunicación y prensa está estrechamente vinculado a unos principios que pueden alterar la realidad (Gans, 1979; Rodrigo, 1989):

- Principio de proximidad geográfica y por zona de influencia

El "sentimiento de pertenencia" es primordial para sentir empatía con lo ocurrido y darle la importancia que merece a la noticia. El suceso tendrá mayor impacto y capacidad de despertar una respuesta en la población si ocurre cerca de nuestro entorno habitual. Se presta mayor atención si el asunto ocurre dentro de nuestro país, así como en países cercanos o que forman parte de un mismo conjunto o bloque cultural o económico como es el caso de la Unión Europea. Se hace también distinción entre los países desarrollados y los menos desarrollados, siendo significativo si ocurre en un espacio cultural similar (Díaz, 2008; Túñez y Guevara, 2009). Por lo general, nos sentimos más identificados con países próximos como Reino Unido, Francia, Portugal o Italia, por la proximidad cultural y socioeconómica. En base a este principio se pueden citar algunos factores que favorecen que un suceso cause mayor impacto en la población:

a) Cercanía geográfica al entorno habitual. Siempre se dará mayor importancia a un suceso que ocurra en el entorno nacional, seguido de los países colindantes al nuestro.

b) Pertenencia a un mismo grupo, comunidad u organización. Por el sentimiento de pertenencia o afiliación que tengamos con el área afectada. Al encontrarnos en un mismo grupo de países como es la Unión Europea (UE), la Organización de las Naciones Unidas (ONU), la Organización del Tratado del Atlántico Norte (OTAN), los países integrantes se comparten el dolor antes acciones como el terrorismo y en determinados casos tienen obligación de prestarse ayuda militar y de seguridad, como en el caso de la OTAN.

c) Países similarmente avanzados. Se siente una mayor empatía si ocurre en un país con cultura similar porque los niveles de seguridad y protección también serán parecidos. Ante un hecho de este tipo, se genera la percepción de que también podría pasar en nuestro país.

d) Países con los que se comparten relaciones económicas y sociales. Causará mayor impacto una noticia en un país con el que se mantienen notables conexiones, ya que en este caso existirá un importante flujo de viajeros nacionales y del país referido por la noticia. Estos hechos afectarán a las relaciones económicas.

Este último factor citado aumenta el impacto de un acto terrorista porque, aunque sucede en un país concreto, puede afectar a muchos más países si las víctimas tienen procedencia extrajera. El turismo incrementa el eco de las acciones terroristas. Un riesgo estrechamente 
relacionado con el principio de proximidad geográfica es que la población tiende a agrupar países próximos en un mismo conjunto. Que ocurra un ataque terrorista en Portugal, por su cercanía o proximidad, también afectará a España y no solo por las potenciales víctimas españolas, sino porque los medios internacionales pueden agrupar e identificar a ambos países con igual riesgo de sufrir un atentado debido a su cercanía cultural y geográfica (Díaz, 2008).

- Principio de periodicidad o regularidad de la incidencia

La normalidad influye en el orden y la importancia de una noticia respecto a otra. La información se abrevia si la noticia sucede habitualmente porque la sociedad se acostumbra e incluso se cansa de recibir hechos similares. Sin embargo, cuando una noticia tiene lugar de forma esporádica, impacta más en la población y se requiere más espacio para explicar lo ocurrido (Túñez y Guevara, 2009).

El desconocimiento sobre la realidad de los países de Oriente Próximo junto con la percepción como área insegura, se acentúa con la difusión de incidentes terroristas. La mayoría de la población occidental identifica estos países como un solo grupo, al que se van sumando la información generada por los diferentes conflictos que surgen en los países de la zona. No se hace una diferenciación por países, es una suma global (Louassini, 2003).

- Principio de predilección de los intereses propios

La vinculación económica entre el estado afectado por el terrorismo y el país del medio de comunicación que divulga la noticia es fundamental para entender el tratamiento de la información. Los medios tendrán una mayor consideración, delicadeza o de forma más detallada sobre el citado país, si hay unas intensas relaciones comerciales, siendo el turismo un elemento decisivo (Herman y Chomsky, 1988; Wu, 2008). Una crisis en un país vecino puede causar un descenso económico serio en el propio país.

\section{METOdOLOGÍA}

Este estudio es un análisis documental y una reflexión teórica que analiza diferentes incidentes terroristas acontecidos desde el año 2015 hasta 2017, localizados en países en los que el turismo tiene un peso económico notable, en Europa y entorno de la cuenca de Mediterráneo.

Este trabajo ha realizado una amplia recopilación documental de noticias relacionadas con el turismo y terrorismo, ubicadas en diversos portales de prensa y de noticias. Para examinar cómo se difunde la información, se ha utilizado la hemeroteca de los principales diarios de España (El País, El Mundo, ABC, La Vanguardia), algunos extranjeros (Washington Post, Le Monde y The Guardian), Agencias de Noticias (EFE, Europa Press, CNN y Reuters), diarios on line especializados en turismo y generalistas. Para el análisis de los diarios del mundo árabe,

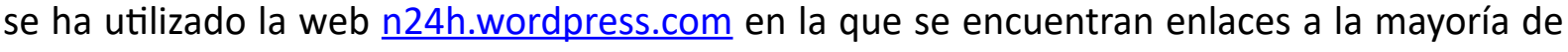
los diarios relevantes del mundo musulmán. Esta documentación se ha utilizado tanto para el apoyo teórico sobre los conceptos desarrollados en la investigación como para el análisis del 
impacto de algunas noticias. Así mismo, se ha empleado material audiovisual de televisión española.

Se ha utilizado la base de datos global (Global Terrorism Database, 2018), que ofrece un listado enumerado de los incidentes terroristas producidos en todo el mundo. Estos se pueden clasificar por fecha, víctimas, tipología, región y país. Además, esta base de datos proporciona mapas que muestran la evolución, concentración e intensidad de los actos terroristas por zonas geográficas.

Para conocer la evolución del panorama turístico de los países relacionados con actividades turísticas, se ha utilizado las fuentes estadísticas de la Organización Mundial del Turismo. También se ha empleado las fuentes estadísticas de los países afectados. Se analizan diversos casos ligados a atentados terroristas concretos (Barcelona y Cambrils, Niza y la situación general de países turísticos especialmente afectados por el terrorismo como los casos de Turquía, Egipto y Túnez).

Se ha estudiado la gestión de la información en situaciones de crisis terrorista para proteger la imagen del destino o país, analizando algún caso concreto. Para conocer el tratamiento de los medios de comunicación ante sucesos terroristas en diferentes áreas geográficas, se examinan algunos acontecimientos en fechas similares.

\section{ANÁLISIS Y RESULTADOS}

\subsection{El turismo como blanco terrorista. Estudio de regiones y países}

Aunque la percepción de la opinión pública en Europa Occidental es que los atentados terroristas contra turistas y actividades turísticas son numerosos, los datos estudiados nos muestran que sólo suponen una pequeña proporción del total, un 0,16\% entre 2010 y 2017 (Global Terrorism Databe, 2018). La mayor parte de los atentados terroristas se dirigen contra las fuerzas armadas, policía, negocios y población civil en general. En el contexto internacional, entre 1990 y 2017 se produjeron 378 atentados con un objetivo claramente turístico, que se localizaron fundamentalmente en países turísticos (Gráfico 2). Europa sufrió el 15,9\% de los atentados de este tipo (Global Terrorism Databe, 2018). Los países que más atentados con fines turísticos han registrado entre 1990 y 2107 son por este orden: Egipto, Yemen, India, Turquía, y entre los países europeos destacan, España, Francia e Italia. La percepción del incremento de inseguridad en Europa Occidental se debe al aumento muy significativo del número de víctimas en los últimos tres años (2015-2017), así como el aumento de incidentes (Gráfico 2). Este aumento obedece a grandes atentados contra población civil (atentado de París en 2015, atentado de Niza, Bruselas y Grecia en 2016 y atentados de Barcelona y Manchester en 2017). En los últimos años los grandes atentados en Europa occidental han sido provocados por grupos yihadistas y aunque no han tenido un fin únicamente contra el turismo, si ha afectado gravemente al mismo. Con anterioridad, los atentados contra el turismo han provocado un número muy limitado de víctimas y han estado ligados a grupos independentistas, destacando ETA y los grupos terroristas de Irlanda del Norte y Córcega. 
Si se hace un repaso cronológico de los atentados producidos en Europa occidental desde enero del 2015 hasta diciembre de 2017, la zona ha sufrido 12 grandes ataques terroristas (más de 10 muertos) y 897 incidentes ligados al terrorismo que produjeron 476 muertos (Tabla 1, Gráfico 1 y 2). Esta situación contrasta con los tres años anteriores, entre 2012 y 2014, durante los cuales se produjeron 31 víctimas mortales en 669 incidentes, de los cuales ninguno de ellos superó los 10 muertos (Global Terrorism Database, 2018). Esta situación explica la percepción del incremento de la inseguridad. Europa desde el comienzo del siglo XXI ha sufrido 708 muertes por terrorismo; España y Francia concentran la mayoría de víctimas mortales con el 73.02\% (España, con 267 fallecidos, 37,71\%; Francia con 250 fallecidos, $35,31 \%)$ (Global Terrorism Database, 2018). Estas cifras aun siendo llamativas, son reducidas en comparación con el número de fallecidos que se ha producido fuera del continente europeo (El Diario, 2016).

Las actividades terroristas están teniendo un notable impacto mediático y social. Este hecho se traduce en un incremento de la solidaridad de la población europea ante estos actos y un aumento de la desconfianza hacia el extranjero (Korstanje, 2011).

Gráfico 2. Incidentes terroristas relacionados con fines turísticos específicos en el mundo y víctimas provocadas por el terrorismo en Europa Occidental (1990-2017

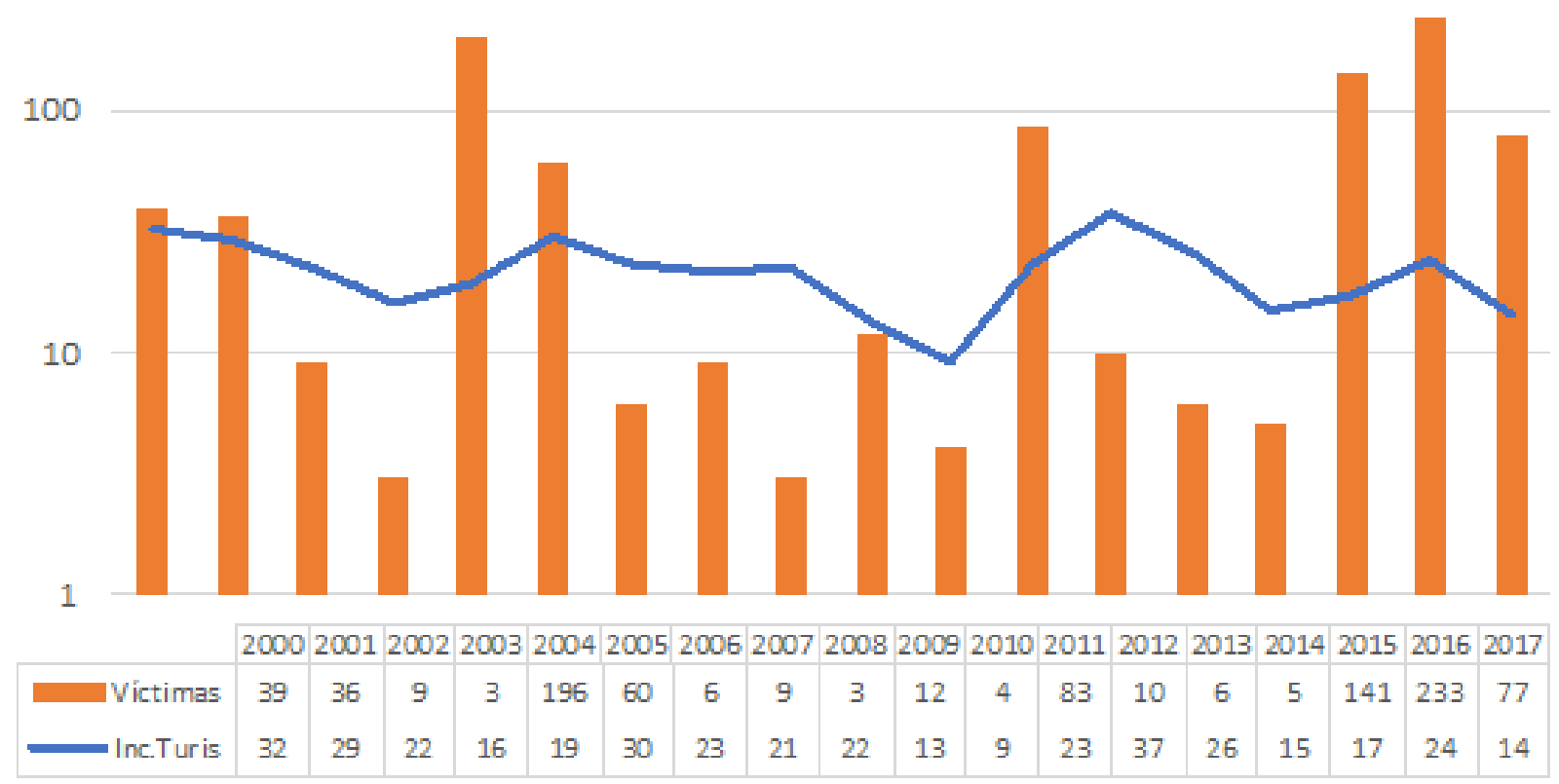

Fuente: Global Terrorism Database, 2018). 
Tabla 1. Recientes actos terroristas en Europa (2015-2017)

\begin{tabular}{|c|c|c|c|c|}
\hline País & Ciudad & Fecha & Víctimas & $\begin{array}{c}\text { Nacionalidades } \\
\text { afectadas }\end{array}$ \\
\hline \multirow{5}{*}{ Francia } & \multirow{4}{*}{$\begin{array}{l}\text { París. Capital de Francia. En varios puntos } \\
\text { del centro y en los Campos Elíseos }\end{array}$} & 07.01 .2015 & \multirow{4}{*}{$\begin{array}{l}156 \text { fallecidos ( } 3 \\
\text { españoles) y } 433 \\
\text { heridos. }\end{array}$} & \multirow{4}{*}{28} \\
\hline & & 09.01 .2015 & & \\
\hline & & 13.11.2015 & & \\
\hline & & 20.04 .2017 & & \\
\hline & $\begin{array}{l}\text { Niza. Atropello en el paseo marítimo de la } \\
\text { capital de la Costa Azul francesa. }\end{array}$ & $\begin{array}{l}14.07 .2016 \\
\text { (Día Nacional } \\
\text { de Francia) } \\
\end{array}$ & $\begin{array}{l}85 \text { fallecidos y } 303 \\
\text { heridos }\end{array}$ & 30 \\
\hline Bélgica & $\begin{array}{l}\text { Bruselas. En el aeropuerto de Zaventem } \\
\text { y en la estación de metro de Maelbeek } \\
\text { (cerca de las instituciones europeas) }\end{array}$ & 22.03.2016 & $\begin{array}{l}35 \text { fallecidos y } \\
340 \text { heridos ( } 9 \\
\text { españoles) }\end{array}$ & 40 \\
\hline Alemania & $\begin{array}{l}\text { Berlín. Atropello en un concurrido } \\
\text { mercado navideño del centro }\end{array}$ & 19.12.2016 & $\begin{array}{l}12 \text { fallecidos y } \\
55 \text { heridos ( } 2 \\
\text { españoles) }\end{array}$ & 14 \\
\hline Suecia & $\begin{array}{l}\text { Estocolmo. Atropello en calle comercial y } \\
\text { peatonal muy transitada }\end{array}$ & 07.04.2017 & $\begin{array}{l}4 \text { fallecidos y } 15 \\
\text { heridos }\end{array}$ & 3 \\
\hline Reino & $\begin{array}{l}\text { Londres. En el famoso puente de Londres } \\
\text { y en Borough Market }\end{array}$ & 03.06.2017 & $\begin{array}{l}11 \text { fallecidos (1 } \\
\text { español) y } 48 \\
\text { heridos }\end{array}$ & 5 \\
\hline & Manchester. Concierto internacional & 22.05.2017 & $\begin{array}{l}22 \text { fallecidos y } 59 \\
\text { heridos }\end{array}$ & 2 \\
\hline España & $\begin{array}{l}\text { Barcelona y Cambrils. Atropello masivo } \\
\text { en temporada de verano, pleno centro } \\
\text { y zona transitada (Las Ramblas) por } \\
\text { visitantes nacionales, extranjeros y } \\
\text { residentes }\end{array}$ & $\begin{array}{l}17.08 .2017- \\
18.08 .2017\end{array}$ & $\begin{array}{l}16 \text { fallecidos y } 152 \\
\text { heridos }\end{array}$ & 34 \\
\hline
\end{tabular}

Fuente: Elaboración propia

En el gráfico 3 se observa como el terrorismo es bastante activo en países de Oriente Medio (Afganistán, Pakistán e India), Oriente Próximo (Irán, Irak, Arabia Saudí, Sudán, Siria, Yemen...) y el continente africano. En 2016, la región que más sufrió la actividad terrorista fue Oriente Medio y Norte de África con un 45,2\% sobre el total mundial, seguido por Asia Meridional $(26,9 \%)$ y África Subsahariana (15,9\%). Europa solo representó un $2 \%$ y Norteamérica un 0,5\% de los 13.488 incidentes terroristas de 2016 (Global Terrorism Database, 2018). Estos porcentajes no han variado mucho en el último decenio.

Pakistán ha sido identificado por Global Terrorism Database como el lugar más peligroso del mundo en relación al terrorismo. Nigeria es otro país con una gran actividad terrorista, al que los medios occidentales suelen prestar bastante atención. El grupo terrorista nigeriano de vertiente yihadista, Boko Haram, es identificado por el Institute for Economics and Peace (2015), como uno de los más peligrosos, sobre todo para mujeres y niñas. Estas actividades enfocadas a la población femenina generan una gran repulsa en los medios de comunicación occidentales (Korstanje, 2011). Según el gráfico 3, en el año 2016 había varias zonas europeas afectadas por un terrorismo de baja intensidad, en comparación otras zonas. Los países señalados son Francia, Bélgica, Alemania, Grecia, Reino Unido y Rusia. 
Gráfico 3. Mapamundi de la concentración e intensidad de actos terroristas (2016)

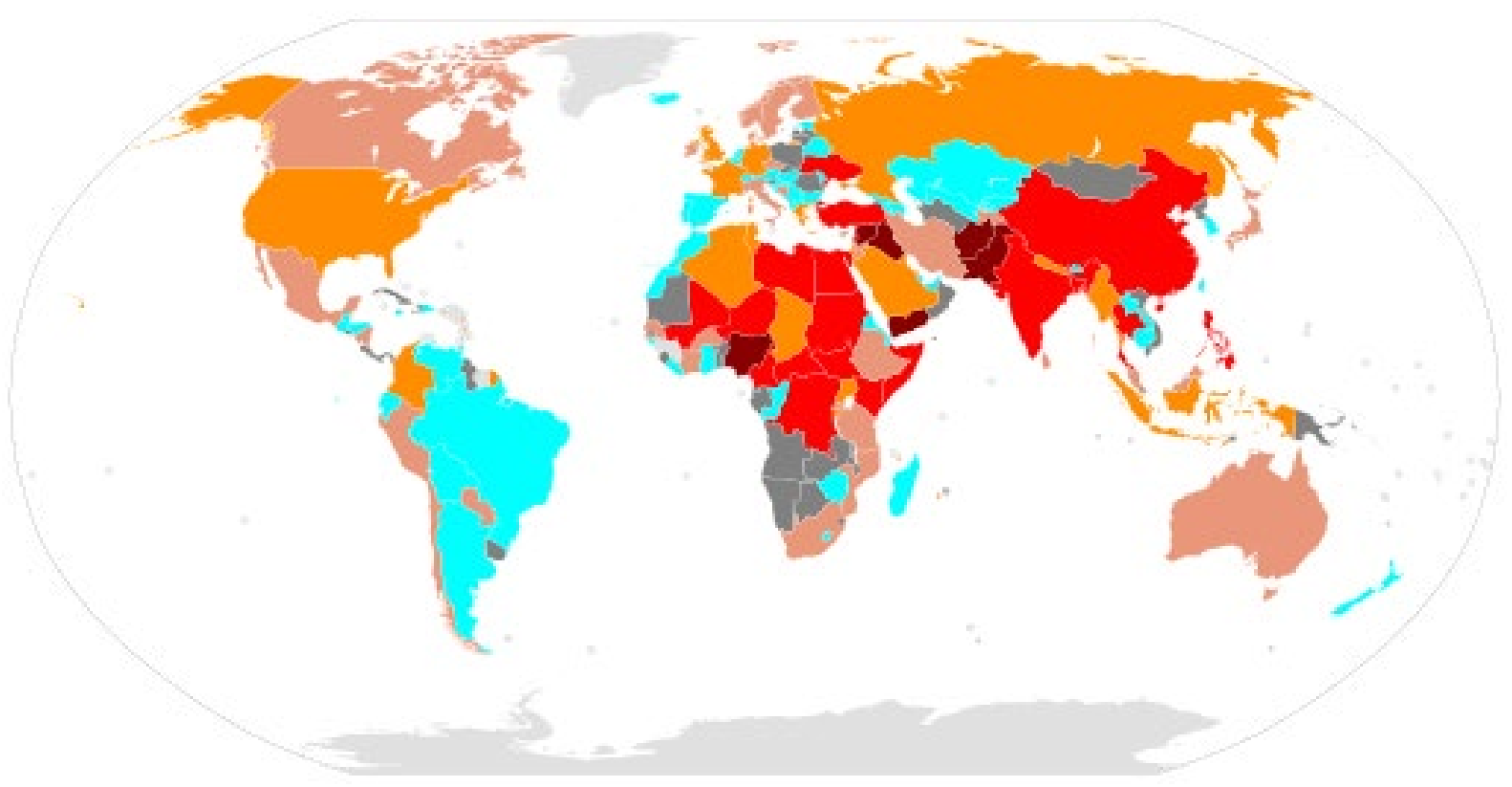

Fuente: Global Terrorism Database. Creative Commons.

El terrorismo yihadista tiene una especial fijación con las sociedades y países occidentales, ya que considera a estos países como generadores de valores que están en contra del islam (Pérez, 2015). Una de las prácticas que desarrolla las sociedades occidentales es el turismo, que es considerado por estos grupos como una actividad que difunde valores que atacan directamente a la comunidad islámica, y que, por otro lado, tiene una gran difusión internacional (Pleterski, 2010). Europa y la cuenca del Mediterráneo es la principal región turística del mundo, por lo que no extraña que buena parte de los ataques terroristas con objetivos turísticos se produzcan en esta zona. De forma general, se pueden plantear al menos tres razones por las cuales el terrorista islámico utiliza el turismo como objetivo (Baumert y Caro, 2010):

a) Permite convertir un atentado "nacional" en internacional.

b) El turismo tiene un inmediato eco en los medios de comunicación, tanto más, cuanto más diverso sea el origen de las víctimas.

c) Al centrarse en objetivos extranjeros y no causar víctimas entre su población de origen, puede seguir contando con su apoyo y encubrimiento.

Tabla 2. Incidentes terroristas en algunos países

\begin{tabular}{|c|c|c|c|c|c|c|c|}
\hline & 2016 & 2015 & 2014 & 2013 & 2012 & 2011 & 2010 \\
\hline Egipto & 355 & 582 & 347 & 310 & 49 & 18 & 2 \\
\hline Túnez & 12 & 17 & 23 & 29 & 1 & 3 & 0 \\
\hline Francia & 26 & 36 & 14 & 12 & 65 & 8 & 3 \\
\hline Bélgica & 6 & 0 & 2 & 0 & 1 & 0 & 0 \\
\hline España & 3 & 1 & 4 & 5 & 1 & 0 & 3 \\
\hline
\end{tabular}

Fuente: Global Terrorism Database, 2010-2016 
En otros países turísticos no europeos y de la cuenca del Mediterráneo, el terrorismo también ha ocasionado graves perjuicios que han generado una profunda crisis económica en los países afectados. Un buen ejemplo de esta situación es Egipto, que es el país que más ha sufrido ataques a zonas turísticas. Egipto ha registrado una notable reducción de flujos de turistas internacionales del 180\% (OMT, 2010-2016) (Gráfico 4). Este país es uno de los países que mayores pérdidas económicas ha padecido a raíz de los atentados terroristas (La Vanguardia, 2014; El Diario, 2014; RTVE, 2016). La Primavera Árabe supuso una reducción de los visitantes (2011) pero el descenso se ha intensificado entre 2015 y 2016 debido a los atentados terroristas (El Cairo, 8 de enero de 2016) y la falta de seguridad aérea, causada por los dos ataques terroristas y un intento de secuestro en un vuelo de EgyptAir (ABC, 2016). Esto dio lugar en 2015 a una reducción del 5\% de los vuelos internacionales y a una multitud de cancelaciones (Rusia y Reino Unido prohibieron incluso toda conexión aérea con el destino) (Europa Press, 2016). La inestabilidad política se ha unido a los atentados terroristas lo que ha producido un fuerte descenso de los ingresos por turismo y de su peso en el PIB (se pasó de un $11,3 \%$ antes de las revueltas y actos terroristas a un 3,5\%) (OMT, 2010-2016). Egipto, el que fuera en 2010 el principal receptor de turismo en África, recibió en 2016 menos turistas que Túnez (Gráfico 4).

Gráfico 4. Entrada de turistas internacionales

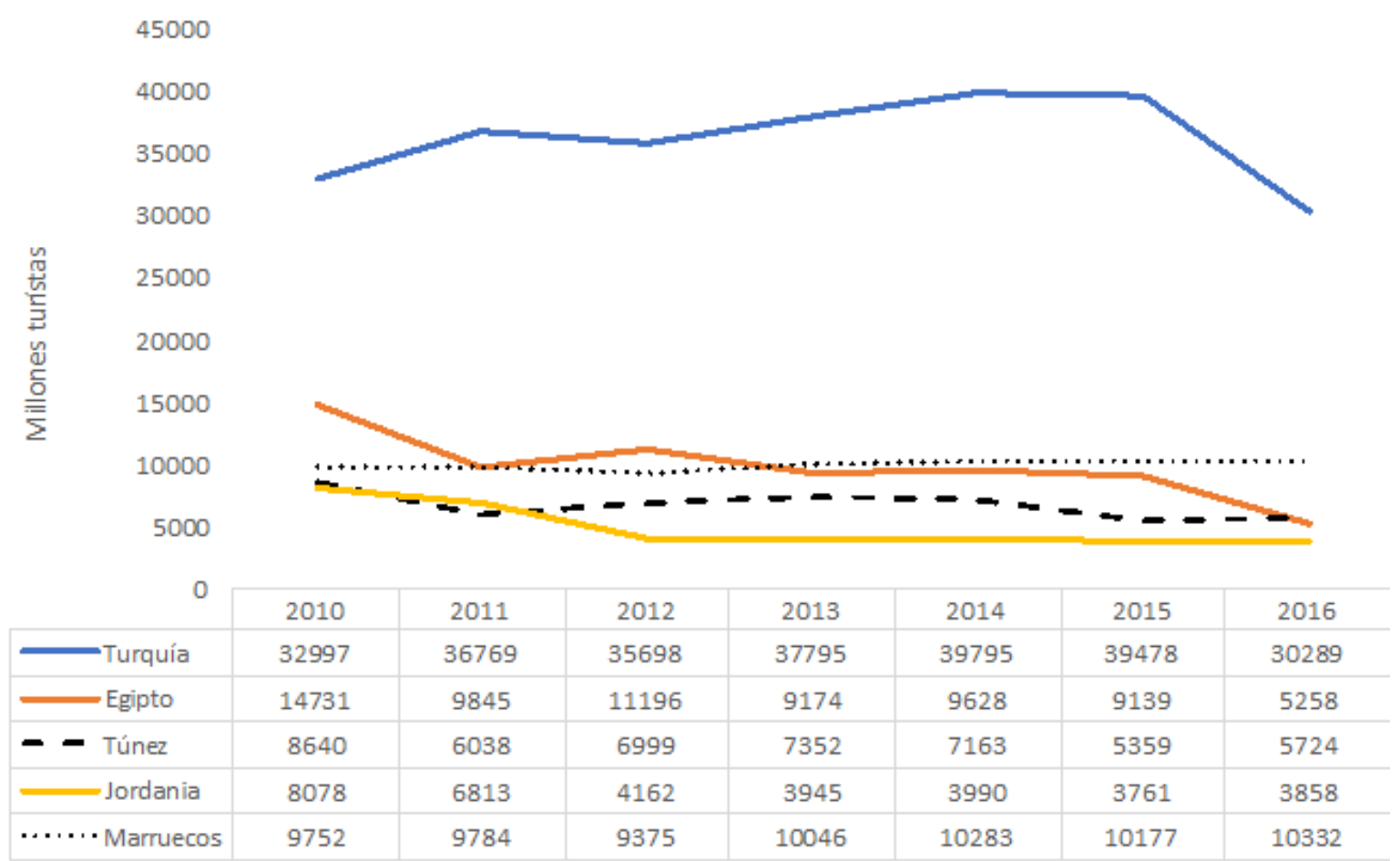

Fuente: Organización Mundial del Turismo (2010-16)

Otro ejemplo es Túnez, considerado impulsor de la Primavera Árabe y defensor de un sistema político democrático. El terrorismo pretende desmontar su evolución hacia una democracia occidental, y ha utilizado los atentados como herramienta política y económica. 
Por ello, Túnez ha sido víctima de graves atentados que han conseguido dañar gravemente la imagen turística y la economía del país. El 18 de marzo de 2015 se produjo un atentado en el Museo Nacional del Bardo, en la ciudad de Túnez, que causó 24 fallecidos y afectó a 19 turistas de 10 nacionalidades diferentes, incluyendo a 2 españoles. A comienzo del verano, el 26 de junio de 2015, tuvo lugar un nuevo atentado, en este caso en un hotel-balneario en Susa (frente al hotel Riu Imperial Marhaba), en la costa mediterránea, donde fallecieron 39 civiles de 8 nacionalidades distintas.

Como se puede observar en el gráfico 4, la Primavera Árabe en 2010 ha supuesto un serio descenso en la recepción turística de Túnez. Posteriormente los atentados de 2015 han agravado la situación. A la escasa diversificación de la economía de Túnez, basada en la actividad turística, se suma la inestabilidad política que compromete claramente la mejora de la economía del país. Casi el $50 \%$ de los ingresos del país proceden del turismo internacional. Los malos resultados económicos han provocado el cierre de multitud de empresas turísticas como restaurantes, comercios y hoteles. Los turistas que siguen visitando el país se alojan bajo el régimen de todo incluido en resorts, en busca de una mayor seguridad, lo que genera un reducido impacto económico fuera de los complejos turísticos. Los turoperadores ofertan el destino con fuertes descuentos y muchos gobiernos pusieron restricciones para no visitar el país, dando como resultado una bajada del $40 \%$ del turismo internacional (Documentos TV, 2017).

Turquía no se vio afectada por la Primavera Árabe, en relación a la recepción turística. La llegada de turistas ha crecido en los últimos años, pero los atentados terroristas de 2016, la inestabilidad política interna (intento de golpe de estado en julio de 2016) y la cercanía de la guerra de Siria, han afectado muy negativamente a la actividad turística (gráfico 4). Es el país de la cuenca del Mediterráneo que más turismo ha perdido en términos absolutos, casi 9 millones de turistas, lo que supone un descenso del 22,8\% entre 2015 y 2016.

Durante 2016 se produjeron tres atentados terroristas: Estambul (12 de enero de 2016 y 28 de junio de 2016) y Ankara (13 de marzo de 2016). Estos tuvieron lugar en dos zonas simbólicas y estratégicas para el turismo, uno de ellos cerca de la transitada Mezquita Azul y el otro en el aeropuerto internacional de Atatürk. Afectaron a turistas de 13 nacionalidades distintas (51 civiles fallecidos y 260 heridos). En su capital, Ankara, murieron 37 personas y 122 resultaron heridas debido a la explosión de un coche bomba. La situación de inestabilidad política de años anteriores culminó en un muy difundido golpe de Estado que ocasionó 241 fallecidos y 2000 heridos (julio 2016).

Los índices turísticos en Turquía han descendido hasta un 40\% en 2016, según Müberra Eresin, vicepresidenta de la federación de hoteleros de Turquía (Agencia EFE, 2016). Las ventas en comercios han caído un $80 \%$ y los hoteles quedaron ocupados solo al $49,7 \%$ de su capacidad (Agencia EFE, 2016). Rusia ha sido uno de los causantes de estas pérdidas, al volver a solicitar visitado para sus turistas y desaconsejar el viaje a Turquía. La reducción de viajeros hacia Turquía se ha producido principalmente a Europa, en 2016 se estimó una bajada del 30\% 
de turistas españoles (Hosteltur, 2017). El mantenimiento de algunos de factores que afectan a la seguridad del potencial viajero (repetición de ataques terroristas, proximidad al conflicto de Siria e Irak), pronostica que aún no habrá una efectiva recuperación de la actividad turística en 2017. Durante 2018 a lira turca ha sufrido una fuerte devaluación, lo que unido a una mayor estabilidad política y a la ausencia de grandes atentados, ha permitido una recuperación de la actividad turística.

\subsection{Estudio de algunos casos en ciudades europeas}

El último atentado terrorista de base islámica producido en España (Barcelona y Cambrils, agosto de 2017) tuvo lugar en el periodo de máxima actividad, agosto, y en un escenario relevante desde el punto de vista turístico, el Paseo de las Ramblas. El atentado afectó a 34 nacionalidades distintas, lo que pone de relieve la internacionalidad del turismo de Barcelona y el eco a que dio lugar en los distintos medios internacionales. Según representantes de Agencias de Viajes, el atropello en Barcelona se localizó en esta ciudad debido a que es uno de los destinos más turísticos de Europa (Valenciaplaza, 2017). Barcelona tiene una gran dependencia del turismo, ya que entre el 10 y $12 \%$ del PIB de la ciudad de Barcelona procede del turismo y proporciona empleo a 90.000 personas (Dirección de Turismo del Ayuntamiento de Barcelona, 2017). Barcelona es una de las ciudades más visitadas en España, en 2017 alojó a 7,7 millones turistas en hoteles (INE, 2017). El número de turistas en 2017 aumentó de forma global un 2,64\% respecto a 2016 y un 83\% respecto a 2015 (INE, 2016, 2017).

El atentado de Barcelona en agosto en 2017 supuso un descenso general del 2,12\% del número de turistas alojados en hoteles, respecto a 2016 (Gráfico 3). Este descenso fue más evidente entre los turistas nacionales $(-11,65 \%)$ que entre los visitantes extranjeros $(-0,4 \%)$. Estos últimos probablemente recibieron menos información desde los medios de comunicación de sus países y mantuvieron las visitas previstas. Los viajeros nacionales recibieron mayor cantidad de información y modificaron sus previsiones de vacaciones.

Esta situación contrasta con los acontecimientos políticos y sociales que se produjeron en los meses posteriores en Barcelona y Cataluña. Las actividades políticas de octubre de 2017 y meses posteriores repercutieron más negativamente entre los turistas internacionales que entre los nacionales. Los turistas internacionales mostraron un descenso del $-3,88 \%$ en octubre de 2017, frente al $-1,12 \%$ de los nacionales (Referéndum de 1 de octubre); en los meses de noviembre y diciembre de 2017 los foráneos han tenido un comportamiento mucho más negativo que los nacionales (INE, 2016, 2017). Este hecho está en consonancia con el tratamiento que los medios internacionales han dado a la situación política de Cataluña. Es llamativo que un ataque terrorista haya producido un menor descenso en la llegada de viajeros internacionales que un acontecimiento político. Esta situación es acorde con las afirmaciones de algunos autores (Fuller, 2017), que señalan que la recuperación del flujo de turistas tras un ataque terrorista es más rápida que la vuelta a la normalidad debida a un clima político inestable. Habitualmente, en 13 meses se produce la recuperación de la normalidad turística tras un ataque terrorista. Esta situación está relacionada con el número de noticias y el mantenimiento de las mismas en el tiempo. 
Gráfico 5. Llegadas de turistas a la ciudad de Barcelona. 2016 y 2017

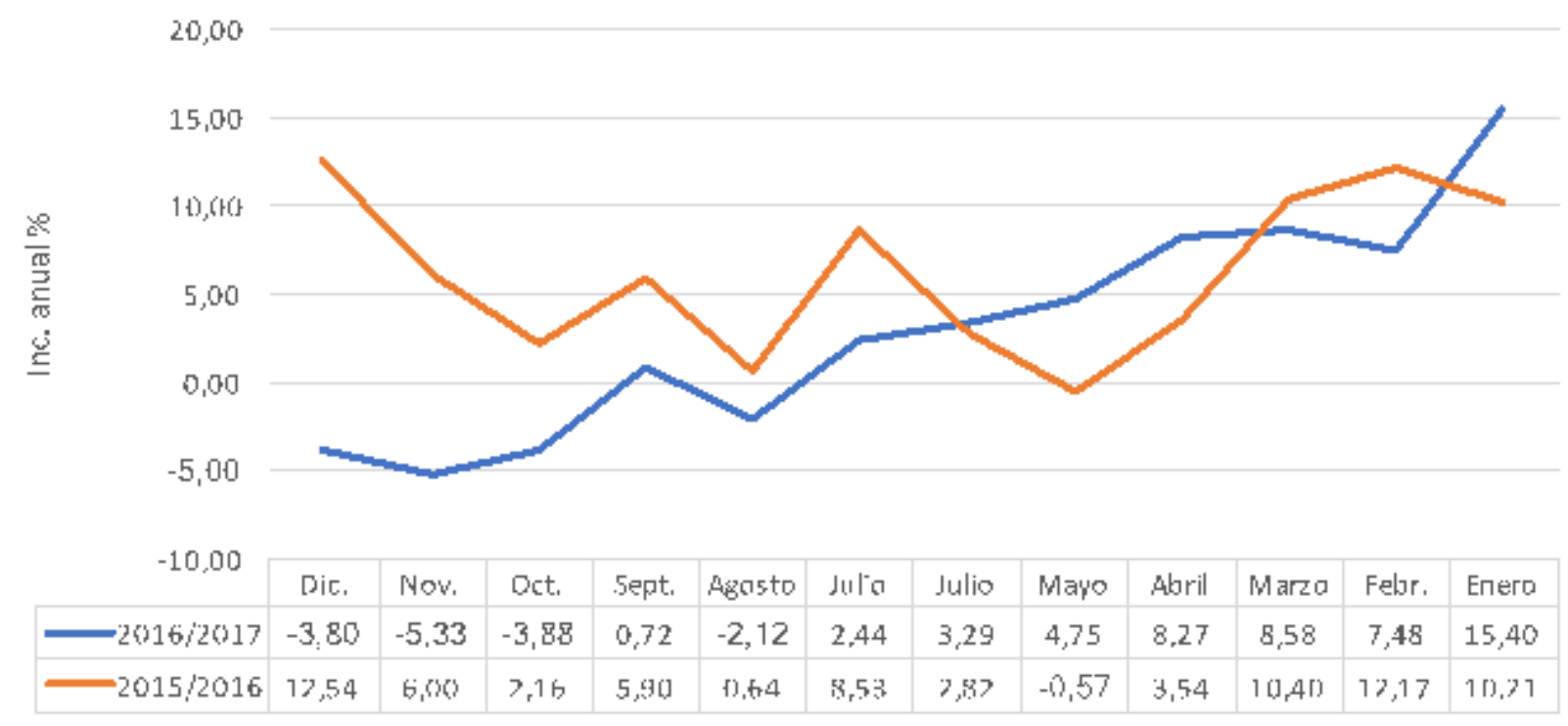

Fuente: INE, 2016 y 2017.

Junto con la descripción del atentado de Barcelona y Cambrils, consideramos interesante recoger las reacciones inmediatamente posteriores al mismo.

Tras el incidente de Cataluña, la reacción de la sociedad fue de solidaridad. Los medios de comunicación gráficos trasmitieron las imágenes de solidaridad ligadas a los pequeños monumentos que espontáneamente se crearon, así como escenas de la vida cotidiana (RTVE, 2017). También se mostraron imágenes de representantes de la política y de la seguridad, destacando la unidad de acción y el trabajo eficaz de las fuerzas de seguridad, aunque flotaba cierta suspicacia debido a la crisis política catalana. Se presentó una escenografía que mostraba las imágenes e ideas de trabajo coordinado, protección, y transparencia informativa para mejorar la confianza del ciudadano local y del potencial turista. Es una escenografía ya ensayada en otras crisis nacionales e internacionales y que tiene una gran relevancia para los medios de comunicación (Rojas, 2003; Losada, 2010).

La idea de que el atentado fue un hecho aislado, azaroso y dentro de un marco de situación controlada, fue destacada por diversos representantes políticos y económicos. La alcaldesa de Barcelona en esa fecha, Ada Colau, ahondó en ese mensaje de "unidad y confianza" y "defendió la proactividad municipal para dar respuesta al impacto que pueda generar" el atentado (La Vanguardia, 2017). Por su parte, el teniente de alcalde del consistorio barcelonés, Jaume Collboni, afirmó que sólo se han producido "cancelaciones menores" sin grandes descensos en las reservas turísticas (La Vanguardia, 2017). Los representantes económicos del turismo de Barcelona también transmitieron esa sensación de normalidad y convocaron rápidamente una rueda de prensa para transmitir normalidad. Los turoperadores destacaron a través de los medios de comunicación la ausencia de cancelaciones de eventos, la apertura 
de todos los monumentos, y que en doce horas las Ramblas estaban abiertas al público (La Vanguardia, 2017). El vicepresidente ejecutivo de Exceltur, José Luís Zoreda, tras el ataque en Barcelona, afirmó que "no creo que se deteriore la imagen de seguridad del país. España está gestionando el acto con una enorme altura de miras y la capacidad de respuesta nos coloca en una posición diferencial" (Expansión, 2017). En resumen, se puede señalar que las acciones tomadas por los representantes políticos y económicos funcionaron adecuadamente; los medios siguieron un "protocolo" ya ensayado en otras catástrofes y la población respondió adecuadamente a este protocolo.

El atentado terrorista del 16 de julio de 2016 en Niza (Francia), tuvo ciertas similitudes al de Barcelona. Fue cometido por terroristas yihadistas, se produjo en destino turístico muy reconocido, en temporada alta y más concretamente en el día nacional de Francia. Este atentado tuvo una mayor repercusión sobre el flujo turístico de la ciudad que en el caso de Barcelona: en julio descendió casi un 5\%, un 13\% en agosto, un 10,4\% en septiembre y 8,5\% en octubre (L'Observatoire du Tourisme de la Côte d'Azur, 2017). Este suceso afectó a la imagen del destino, además era continuación de otros atentados que se habían producido en Francia en enero y noviembre de ese mismo año (Expansión, 2016) (Tabla 1 y 2). Esta situación dio lugar a un descenso del $11 \%$ de los vuelos regulares a Niza. El turoperador TUI aconsejó anular o cancelar los viajes a este destino, por lo que varios eventos y vuelos fueron cancelados (Expansión, 2016).

\subsection{Comparación de algunas noticias relacionadas con el terrorismo}

A continuación, se analizan y comparan noticias relacionadas con el terrorismo yihadista en fechas próximas y para tres ciudades en destino marco geográfico y cultural:

- El 3 de julio de 2016, dos ataques yihadistas en Bagdad (capital de Irak) perpetrados con un coche bomba mataron a 383 civiles chiíes e hirió a 200 personas durante el Ramadán, cuando se encontraban haciendo compras. Otras cinco más murieron con la segunda bomba en una zona residencial. Este ha sido el ataque más mortífero de Irak en más de una década.

- El 14 de julio de 2016 se produjo un atentado en Niza (Francia), mientras se celebraban el Día Nacional en el paseo marítimo "El Paseo de los Ingleses" justo antes de la temporada de verano. Este atentado se realizó con un camión que embistió a transeúntes de 30 nacionalidades distintas (85 víctimas mortales y 303 heridos).

- El 22 de julio de 2016 se produjeron dos ataques suicidas con cinturones bomba contra una huelga de la minoría étnica hazara en Kabul (capital de Afganistán). Hubo 80 víctimas mortales y 230 heridos. Ashraf Gani, presidente afgano, aseguró que entre los fallecidos y heridos había miembros de seguridad y defensa que trabajaban para proporcionar seguridad a los manifestantes que celebraran su derecho a protestar (RTVE, 2016). 
Tabla 3. Número de entradas de las noticias seleccionadas según medios de comunicación

\begin{tabular}{|c|c|c|c|c|c|c|c|c|c|}
\hline & $\begin{array}{c}\text { Agencia } \\
\text { EFE } \\
\text { (España) }\end{array}$ & $\begin{array}{c}\text { Washington } \\
\text { Post (Estados } \\
\text { Unidos) }\end{array}$ & $\begin{array}{c}\text { Diario } \\
\text { El País } \\
\text { (España) }\end{array}$ & Le Monde & $\begin{array}{c}\text { The } \\
\text { (Francia) } \\
\text { Guadian } \\
\text { (Reino } \\
\text { Unido) }\end{array}$ & $\begin{array}{c}\text { Al } \\
\text { Jazeera } \\
\text { (Catar) }\end{array}$ & $\begin{array}{c}\text { Al Sharq al } \\
\text { Awsat } \\
\text { (Magreb y } \\
\text { Marruecos) }\end{array}$ & $\begin{array}{c}\text { Al Bayán } \\
\text { (Dubai) }\end{array}$ & $\begin{array}{c}\text { Al Ajbar } \\
\text { (El } \\
\text { Líbano) }\end{array}$ \\
\hline $\begin{array}{c}\text { Atentado } \\
\text { Niza }\end{array}$ & 1.494 & 482 & 996 & 1.659 & 2.100 & 16 & 1 & 3 & 2 \\
\hline $\begin{array}{c}\text { Atentado } \\
\text { Bagdad }\end{array}$ & 4 & 1 & 2 & 1 & 6 & 10 & 6 & 6 & 3 \\
\hline $\begin{array}{c}\text { Atentado } \\
\text { Kabul }\end{array}$ & 1 & 1 & 1 & 1 & 1 & 4 & 0 & 11 & 2 \\
\hline
\end{tabular}

Fuente: Elaboración propia

El análisis de las noticias tomadas como referencia, muestra que hay una gran desproporción entre la información disponible del atentado de Niza y los otros dos sucesos. La cercanía geográfica y cultural se cumple en el estudio planteado, presentado un mayor interés los medios de comunicación europeos por el atentado de Niza que la prensa norteamericana y la del mundo árabe (Tabla 3). Incluso es probable que los atentados de Bagdad y Kabul hayan quedado oscurecidos en el análisis de los medios, ya que estos se produjeron en fechas próximas al atentado de Niza y éste tuvo una gran cobertura en los medios. Tanto el atentado de Kabul como Bagdad apenas se mantienen un día o dos en la prensa, mientras que el suceso de Niza se prolonga ampliamente en el tiempo, habiendo entradas de noticias del mismo en 2018.

De forma general, las agencias de noticias y los repositorios de los medios de comunicación proporcionan para los países europeos, vecinos o desarrollados multitud de noticias, artículos, entrevistas, informes, etc., además de la información en las redes sociales e informativos. Esto permite conocer la noticia con detalle: el daño, el impacto ocasionado y las previsiones económicas de la zona afectada. Además, este tipo de atentados en Occidente llena las portadas de la prensa y los titulares de telediarios tanto después de ocurrir el incidente (prolongándose una media de siete días), como en años siguientes con los homenajes que se realizan recordando lo ocurrido.

Esto contrasta con la dificultad para encontrar noticias en hemeroteca con datos específicos sobre el impacto del problema en países de Medio Oriente u Oriente Próximo. La información se muestra con menos contenido y con mayor brevedad, así como datos superficiales y mayor ambigüedad del suceso. Resulta casi imposible encontrar informes de valoración ni balances económicos del daño causado. Por otro lado, la prensa solo le dedica un par de días de media para indagar sobre lo ocurrido y mostrarlo en los periódicos, sin protagonizar ninguna portada de los mismos (lo comunican como una noticia secundaria). Una línea más restrictiva muestra los informativos de televisión, cuyas noticias sobre atentados en países no occidentales no suelen presentarse con un titular de salida en la mayoría de las ocasiones, habitualmente se hace una mención secundaria, o simplemente se informa a través de subtítulos desplegables en la parte inferior de la pantalla. 
También se observan diferencias en las imágenes que se muestran en un suceso y en otro. Los medios de comunicación son capaces de controlar la información con un lenguaje escrito y recursos audiovisuales más o menos alarmistas según los intereses del emisor y/o del público receptor. De esta manera, en actos terroristas perpetrados en Oriente Próximo, se han emitido imágenes de víctimas y heridos que impresionan al espectador y transmiten inseguridad. Además, los cuerpos de seguridad y las medidas de control no son mostrados en la mayoría de los casos. El ejemplo contrario lo presenciamos en los incidentes presenciados en territorio europeo, encabezando los titulares o comenzando la noticia con imágenes de los cuerpos de seguridad y las medidas de protección que han acordonado la zona. Además, se respeta a las víctimas al no difundir imágenes del horror cometido y se intenta que estas no sean difundidas por las redes sociales para no causar un mayor impacto o un mayor temor a la sociedad. La imagen que se difunde de la zona europea es de tranquilidad y seguridad, aunque se produzca un acto terrorista, dando a entender que es algo excepcional y que es poco probable que se vuelva a repetirse. Sin embargo, la imagen que se transmite de los actos terroristas en países no europeos es de inquietud, amenaza y falta de seguridad.

De forma general, los medios de comunicación del mundo árabe dan mayor cobertura a los atentados próximos, aunque muestran sus diferencias. Los medios de comunicación en lengua árabe dan más prioridad a los acontecimientos del mundo musulmán, mientras que los medios de comunicación que tienen versiones en inglés o ambas, muestran una mayor cobertura de los atentados en el mundo occidental, siendo un buen ejemplo Al Jazeera. Este medio de comunicación controlado por la familia del Jeque Al Thani, gobernantes de Catar, tiene un canal en inglés u otro árabe. El canal inglés es bastante más proccidental que su versión en árabe. En ambos casos, Al Jazeera responde a los intereses diplomático de Catar (Hernández, 2016). Los otros tres medios en lengua árabe tienen un mayor interés por los atentados en los países árabes.

\subsection{El inestable turismo prestado}

Para entender este término, debemos atender al significado del verbo prestar, que se entiende como dar algo a alguien un cierto tiempo sin que lo integre en sus posesiones de forma permanente. El turismo es "prestado" cuando los índices de visitantes de un territorio aumentan en detrimento de otro competidor que ha sufrido alguna desgracia, pero dicho beneficio se mantendrá hasta que los países afectados se recuperen y su percepción de seguridad se restablezca o bien, hasta que el país, temporalmente favorecido, se vea también afectado por motivos similares. Estos aumentos y decrementos se pueden entender dentro de un "juego de suma cero", en el que todas las piezas están interrelacionadas (Baumert, 2016).

España vive una situación favorable para el sector turístico, posicionándose como destino refugio, alejado de la inestabilidad política y social de sus principales competidores del Mediterráneo, en particular, Egipto, Túnez y Turquía (TecnoHotel, 2016; Moral, 2016). Esto ocasiona que el territorio español se beneficie del crecimiento en la demanda turística extranjera. Desde el año 2010, los turoperadores priman el destino español como oferta principal con respecto a dichos competidores (aunque éstos sean un 15\% más baratos), desviando el $35 \%$ de sus clientes a España (Tobar, 2016). A pesar del atentado de Barcelona y Cambrils, los 
grandes turoperadores europeos han desviado desde 2011 a España el 35\% de los turistas que gestiona (ABC, 2015).

Según la edición anual del 2016 de la Organización Mundial del Turismo (OMT), España se posicionó como el tercer país más visitado del mundo y segundo en ingresos por turismo. En el 2016, el territorio español recibió 75,5 millones de turistas extranjeros (un 4.9\% más que el año anterior) y cerró el año con ingresos de 60.346 millones de dólares (OMT, 2016). Según el Instituto de Estudios Turísticos (2018) esta tendencia al aumento de la recepción turística se ha mantenido y España recibió en 2017 81,8 millones de turistas, lo que supuso un incremento del $8,6 \%$. Por tanto, se mantienen los mismos factores que han permitido el crecimiento de la actividad turística de años anteriores.

Tabla 4. Algunos países ganadores y perdedores de actividad turística. Incremento anual de turistas periodo 2015-2016

\begin{tabular}{|c|c|c|c|}
\hline & $\begin{array}{c}2015 / 2016 \text { Inc. } \\
\text { Anual (\%) }\end{array}$ & $\begin{array}{c}2015 / 2016 \text { Inc. Anual } \\
(\%)\end{array}$ \\
\hline Francia & $-2,2$ & España & 10,3 \\
\hline Bélgica & $-10,5$ & Portugal & 12,7 \\
\hline Turquía & $-22,0$ & Bulgaria & 16,2 \\
\hline Egipto & $-42,5$ & Chipre & 20,0 \\
\hline
\end{tabular}

Fuente: OMT.

Según la OMT (2016), la actividad terrorista ha provocado que algunos países hayan perdido actividad turística, tanto en Europa como en la cuenca del Mediterráneo y que esos flujos turísticos se hayan trasladado hacia algunos países del sur y del este de Europa (Tabla 4). Por tanto, la situación de "éxito" del turismo español que ha vuelto a batir su record de recepción en 2017, obedece en parte al turismo prestado. Esta situación es coyuntural y los países beneficiados tampoco están a salvo de sufrir ataques terroristas y experimentar descensos en la recepción de viajeros. Alguno de los países que más ha sufrido el terrorismo, como es el caso de Túnez, apunta una ligera recuperación en 2016 (Gráfico 4), lo que señala que estas situaciones son cambiantes. Algunos medios de comunicación avanzan que las cifras de turismo de España han disminuido en el verano de 2018, debido a la recuperación de los países de la cuenca de Mediterráneo afectados anteriormente por la actividad terrorista (EI Periódico, 2018).

\section{CONCLUSIONES}

El terrorismo atenta contra destinos y lugares turísticos para generar la mayor difusión posible de sus actos, asegurándose una amplia cobertura de los medios de comunicación. La vinculación de los grandes grupos de comunicación global con los países occidentales, hace que los acontecimientos en los países de este entorno estén mucho más atendidos que en Oriente Próximo o Medio. Los medios de comunicación no son imparciales ni ecuánimes en la 
descripción de estos fenómenos, y seleccionan las noticias en función de criterios acordes a su línea editorial en consonancia con valores y gustos de su público.

Las estrategias de comunicación identificadas por Chomsky (2010) y Ribas (2002) sobre los intereses sociales implícitos en las noticias, han sido señaladas en anteriores apartados. En un mismo periodo de tiempo y ante acontecimientos similares, los medios de comunicación seleccionan las noticias acordes a sus objetivos. Los fallecidos contabilizan de forma diferente en función del lugar de origen, la cercanía geográfica, cultural y económica y el tiempo de selección varía en función de los criterios de selección de las noticias.

Se ha podido comprobar como los medios analizan desequilibradamente los atentados según los países en los que se producen. La mayor parte de los atentados terroristas se localizan en países musulmanes (El Diario, 2016), pero los medios de comunicación occidentales transmiten la idea de que la actividad terrorista está centrada fundamentalmente en Occidente. Los conflictos en países no europeos son presentados dentro de un contexto de constante inestabilidad política, en muchos casos estos países quedan englobados bajo el calificativo de "estado fallido", mientras en Europa son hechos puntuales que "sacan lo mejor de la sociedad", mediante la demostración de pruebas de solidaridad y muestras de actividades de la vida cotidiana.

Por otro lado, la crisis turístico-económica que sufren los países de la orilla sur y este del Mediterráneo a causa del terrorismo tiene una importancia singular. La fuerte dependencia económica que presentan algunos países hacia el turismo hace que éste se haya convertido en un objetivo estratégico para doblegar los gobiernos de estos estados. El turismo posee un valor similar al que puede tener el petróleo en otros países del entorno. De esta forma, la actividad terrorista tiene la triple misión de lograr difundir temor entre los potenciales turistas y desestabilizar económicamente a estos países, además de combatir una actividad que atenta a los principios del islam más conservador.

La importancia que tiene la seguridad en la imagen turística de los destinos turísticos y la fuerte repercusión que pérdida de la misma, invitan a evaluar los procedimientos para la gestión de las crisis generadas por los impactos negativos. No todos los entes de gestión de destinos disponen de gabinete de crisis para la gestión de la comunicación y coordinación de áreas. Si bien, diversos países europeos y occidentales cuentan con una buena gestión y conexión con los medios de comunicación internacionales, esto no quiere decir que la imagen de algunos destinos nacionales o locales puedan verse afectados muy negativamente. La reducción del tiempo de impacto negativo en la imagen de destino, depende en buena manera de la adecuada actuación de los gabinetes de crisis de medios de comunicación. En esta línea, es de gran importancia la existencia de protocolos de actuación, lo mismo que acontece ante el impacto de un fenómeno natural.

La inestabilidad generada por los conflictos políticos y militares, junto al terrorismo ha generado un flujo de turismo "prestado" que está favoreciendo a numerosos países europeos de la orilla norte del Mediterráneo. Este amplio flujo de turismo prestado es bastante volátil y depende de los intereses de las agencias mayoristas, la estabilidad económica y política de los países y de la orientación de la comunicación sobre los destinos. La actividad turística tiene una fuerte vinculación la imagen de destino que es una variable intangible, que se construye a 
lo largo del tiempo generando información y sentimientos positivos y que se puede deteriorar con mucha rapidez con unas pocas noticias negativas. Así pues, al igual que se invierte en seguridad y prevención de atentados, se debería invertir en conocer la resiliencia del turista ante estos fenómenos (Liu y Pratt, 2017), y en desarrollar planes de comunicación y coordinación preventiva para los destinos ante eventos negativos.

\section{REFERENCIAS BIBLIOGRÁFICAS}

ABC: Economía (2015). La Primavera Árabe ha desviado a España más de seis millones de turistas. Recuperado el 27 de abril de 2017, de: www.abc.es/economia/20150402/ abci-turismo-espana-primavera-arabe-201504012203.html

ABC: Internacional (2016). El turismo egipcio se estrella con el MS804. Recuperado el 28 de abril de 2017, de: http://www.abc.es/internacional/abci-turismo-egipcio-estrella-ms804-201605251858 noticia.html

Agencia EFE (2016). El turismo en Turquía cae un 40\% en junio, el mayor desplome en 22 años. Recuperado el 24 de febrero de 2016, de: https://www.efe.com/efe/espana/economia/ el-turismo-en-turquia-cae-un-40-junio-mayor-desplome-22-anos/10003-2999045

Baumert, T. y Caro, J. (2010). The impact of terrorism attacks on passenger's travel behavior: evidences from Spain, in: Adrienne Gallore (2010). Terrorism: motivations, threats and prevention. New York: Nova Publishing, pp. 151-170.

Baumert, T. (2016). Terrorismo y turismo: una revisión de la literatura acerca de la repercusión de los atentados sobre el sector turístico. Información Comercial Española, 893, 51-70.

Berenguer, J.M. (23/08/2916). El terrorismo y la geopolítica cambian el mapa de los destinos turísticos, El Periódico.

Bossong, R. (2012). The evolution of EU counter-terrorism: European security policy after 9/11. Routledge.

Calduch Cervera, R. (2001). La incidencia de los atentados del 11 de septiembre en el terrorismo internacional. Revista española de derecho internacional, 173-203.

Chomsky, N. (2010). 10 estrategias de manipulación mediática. México D.F.: Centro de Estudios del Movimiento Obrero y Socialista.

Díaz Arias, R. (2008). La representación del mundo en los informativos de televisión, Estudios sobre el mensaje periodístico, 14, 363-389.

Documentos TV. (2017, junio 27). Terror en el paraíso. [Archivo de vídeo]. Recuperado el 27 de junio de 2017, de: http://www.rtve.es/alacarta/videos/documentos-tv/ documentos-tv-terror-paraiso/4085763/

El Diario (2014). El número de turistas en Egipto cayó en marzo más de un 32 por ciento interanual. Recuperado el 21 de junio de 2017, de: http://www.eldiario.es/economia/ numero-turistas-Egipto-ciento-interanual 0 259675017.html

El Diario (2016). El 87\% de los atentados yihadistas desde el año 2000 han sido en países de mayoría musulmana. Recuperado el 17 de mayo de 2017, de: http://www. eldiario.es/internacional/atentados-organizaciones-islamistas-mayoria-musulmana_0_497301265.html

El Periódico (2018). El turismo se estanca en España por la recuperación de los países competencia. Recuperado el 7 de septiembre de 2018, de: https://www. 
elperiodico.com/es/economia/20180902/el-turismo-se-estanca-en-espana-por-larecuperacion-de-la-competencia-7012230

Europa Press (2016). La amenaza terrorista convierte en una ciudad fantasma uno de los principales lugares turísticos de Egipto. Recuperado el 25 de abril de 2017, de: http://www. europapress.es/internacional/noticia-amenaza-terrorista-convierte-ciudad-fantasma-principales-lugares-turisticos-egipto-20160405120733.html

Expansión (2017). Así valora el sector del turismo el impacto del atentado de Barcelona. Recuperado el 25 de abril de 2017, de: http://www.expansion.com/empresas/transporte/2017/08/19/59973ac2ca4741da1c8b4594.html

Expansión (2016). El atentado en Niza golpea al sector turístico en Francia. Recuperado el 19 de mayo de 2017, de: http://expansion.mx/economia/2016/07/15/ el-atentado-en-niza-golpea-al-sector-turistico-en-francia

Fuller, E. (2017). Tourism remains resilient in face of global terrorism, World Travel and Tourism Council.

Gans, H. (1979). Deciding what's news. New York: Pantheon Books.

Global Terrorism Database (2018). Global Terrorism Index, Recuperado el 27 de agosto de 2018, de: https://www.start.umd.edu/gtd/

Heath, R. L. y Palenchar, M. J. (2008). Strategic issues management: Organizations and public policy challenges. Editorial: Grupo Sage

Herman, E. y Chomsky, N. (1988). Manufactoring consent. The Political Economy of Mass Media, New York: Pantheon.

Hernández, D. (2016). Al Jazeera mucho más que una television. El orden mundial.com.

Hosteltur (2017). Los ingresos por turismo en Turquía caen a niveles de hace 10 años. Recuperado el 16 de abril de 2017, de: https://www.hosteltur.com/120299 ingresos-turismo-turquia-caen-niveles-hace-10-anos.html

Instituto de Estudios Turísticos (IET) (2018). Movimientos turísticos en fronteras (FRONTUR). Informe anual de 2017. Madrid: Turespaña.

Instituto Nacional de Estadística (INE) (2016-2017). Encuesta de ocupación hotelera. Viajeros y pernoctaciones por puntos turísticos. Madrid: INE.

Instituto Nacional de Estadística (INE) (2017). Encuesta de ocupación hotelera. Viajeros y pernoctaciones por puntos comunidades autónomas y provincias. Madrid: INE.

Institute for Economics \& Peace (2015). Global Terrorism Index: Measuring and Understanding the Impact of Terrorism. Volumen 1, pp. 90-94.

Korstanje, M. (2011). Terrorismo, Turismo y Economía. Consideraciones en torno al terrorismo: el 11 de septiembre y sus efectos colaterales. Argentina. AL Editorial.

Laqueur, W. (2003). No end to war: Terrorism in the twenty-first century. Bloomsbury Publishing. La Vanguardia (2014). El número de turistas en Egipto cayó en marzo más de un 32\% interanual. Recuperado el 8 de abril de 2017, de: http://www.lavanguardia.com/ ocio/20140513/54407882040/el-numero-de-turistas-en-egipto-cayo-en-marzo-masde-un-32-interanual.html

La Vanguardia (2017). Barcelona estima que por ahora el impacto del atentado en la economía local es leve. Recuperado el 30 de agosto de 2017, http://www.lavanguardia.com/ local/barcelona/20170822/43741348465/barcelona-impacto-atentado-economia-turismo.html 
Liu, A. y Pratt, S. (2017). Tourism's vulnerability and resilience to terrorism. Tourism Management. Hong Kong, Japón: Elsevier.

L'Observatoire du tourism de la Côte d'Azur (2017). Evolution du taux d'ocupation. Hôtels et residences, 2015, 2016. Nice: Comité Regional du Tourisme Côte d'Azur.

Losada, J. (2010). Comunicación en la gestión de crisis. Barcelona, España. Editorial: UOC.

Louassini, Z. (2003). La imagen del árabe en los medios de comunicación occidentales, Miscelánea de Estudios Árabes y Hebraicos, 52, 125-146.

Moral, P. (2016). El impacto del terrorismo internacional en la industria del turismo: balance y perspectivas en el Mediterráneo. España. IEEE: Instituto Español de Estudios Estratégicos.

Organización Mundial del Turismo (OMT) (2010-16). Compendio de estadísticas del turismo, Madrid: OMT.

Pérez Luna, E. (2015). Terrorismo Internacional: Orígenes y Evolución del Terrorismo Yihadista (Máster en Relaciones Internacionales). Recuperado el 29 de mayo de 2017 de https:// www.academia.edu/13408649/TERRORISMO INTERNACIONAL OR\%C3\%8DGENES Y EVOLUCI\%C3\%93N DEL TERRORISMO YIHADISTA

Pew Research Center (2015). The Future of World Religions: Population Growth Projections, 2010-2050. Recuperado el 29 de mayo de 2017, de: http://www.pewforum. org/2015/04/02/religious-projections-2010-2050/

Pleterski, T. (2010). El impacto del terrorismo sobre el turismo. Los efectos causados sobre la recepción de visitantes. Trabajo Final de Grado. Universidad Politécnica de Valencia.

Ribas, C. (2002). El Periodismo científico y su relación con el proceso de producción de las noticias en los medios de comunicación de masas. Barcelona, España. pp.503-506. University Pompeu Fabra.

Rojas, O. (2003). La comunicación en momentos de crisis. Revista Científica de Comunicación y Educación, 137-140.

Rodrigo Alsina, M. (1989). La construcción de la noticia. Barcelona: Paidós.

Rodrigo Alsina, M. (1991). Los medios de comunicación ante el terrorismo. Barcelona: Icaria.

Rubio Ferreres, J.M. (2009). Opinión pública y medios de comunicación. Teoría de la agenda setting, Gazeta de Antropología, 25(1).

RTVE (2016). El turismo en Egipto agoniza, las llegadas de turistas cayeron casi un $50 \%$ entre enero y abril de 2016. Recuperado el 25 de febrero de 2017, de: http://www.rtve. es/noticias/20160608/turismo-egipto-agoniza-llegadas-turistas-cayeron-casi-50-entre-enero-abril-2016/1356521.shtml

RTVE (2017). Atentado en Barcelona: Barcelona grita "no tengo miedo" tras el minuto de silencio por los atentados en Cataluña". Recuperado el 18 de agosto de 2017, de: http:// www.rtve.es/noticias/20170818/barcelona-unida-grita-no-tenemos-miedo-minuto-silencio-atentados-cataluna/1599486.shtml

TecnoHotel (2016). El "turismo prestado" se traducirá en un $60 \%$ de demanda turística extranjera adicional en España. Recuperado el 28 de abril de 2017, de: www.tecnohotelnews. com/2016/07/el-turismo-prestado-se-traducira-en-un-60-de-demanda-turistica-extranjera-adicional-en-espana/\# 
Tobar, S. (2016). El turismo en España ¿prestado o real?, Diario 16, Recuperado el 30 de abril de 2017 de: http://diario16.com/el-turismo-en-espana-prestado-o-real/

Túñez, M. y Guevara, M. (2009). Framing por proximidad como criterio de noticiabilidad: la curva de las ausencias, Revista Latina de Comunicación Social, 64.

Veres, L. (2004). Prensa, poder y terrorismo. Amnis. Revue de civilisation contemporaine Europes/Amériques, 4.

Wolf, M. (1987). La investigación de la comunicación de masas. Buenos Aires: Ediciones Paidós.

Wu, H. D. (2000). Systemic determinants of international news coverage: A comparison of 38 countries. Journal of communication, 50(2), 110-130.

Zuinaga, S. (2011). El terrorismo, una aproximación teórica en cuanto a su definición. Revista venezolana de análisis de coyuntura, Vol. XVII (2), jun.-dic., pp. 11-26. 